\title{
STUDI KOMUNITAS FILUM MOLLUSCA DI ZONA INTERTIDAL PANTAI SUKAERLARAN DESA KENEBIBI KECAMATAN KAKULUK MESAK KABUPATEN BELU
}

\author{
Gonsianus Pakaenoni \\ Program Studi Biologi, Fakultas Pertanian Universitas Timor \\ Correspondence Author: pakaenonigonsianus@yahoo.co.id
}

\begin{tabular}{|c|c|}
\hline Info Artikel : & ABSTRACT \\
\hline \multirow[t]{2}{*}{$\begin{array}{l}\text { Keyword : } \\
\text { Mollusks } \\
\text { community, } \\
\text { density, diversity } \\
\text { index, the } \\
\text { dominance index }\end{array}$} & $\begin{array}{l}\text { The area which has recently received considerable attention is the coastal } \\
\text { region/region. This is because the coastal region/region has a diverse wealth } \\
\text { that can be utilized by the surrounding community as a source of the main food } \\
\text { ingredients that are rich in animal protein content. Mollusca comes from Latin } \\
\text { "mollis" which means soft. In addition to the soft body also has a shell that } \\
\text { functions as an outer framework (Rusyana, 2011). The benefits of Mollusca for } \\
\text { humans include as a source of protein, animal feed ingredients, industrial } \\
\text { materials, jewellery, fertilizer materials and medicines (Dibyowati, 2009). This } \\
\text { research was conducted in the intertidal zone of Sukaerlaran beach, Kenebibi } \\
\text { Village, Kakuluk Mesak District, Belu Regency. The results showed that the } \\
\text { density of molluscs ranged from } 4.25 \text { Ind / m2 - } 13.25 \text { Ind / m } 2 \text { which were } \\
\text { spread in } 4 \text { roaming areas. The roam area I has the highest density value of } \\
13.25 \text { Ind / m2. The average value of the relative density of mollusks ranges } \\
\text { from } 0.11 \%-0.34 \% \text {. Of the four roaming areas, roaming areas that have the } \\
\text { highest relative density are range I of } 0.34 \% \text {. The diversity index value in all } 4 \\
\text { home ranges is relatively low. The dominance index value indicates that the } \\
\text { entire range } 4 \text { roaming areas) is in the low category with a range of values } \\
\text { between } 0.0120-0,1169 \text {. }\end{array}$ \\
\hline & \\
\hline $\begin{array}{l}\text { Kata Kunci : } \\
\text { Komunitas } \\
\text { Molluska, } \\
\text { kepadatan, indeks } \\
\text { keanekaragaman, } \\
\text { indeks dominasi }\end{array}$ & 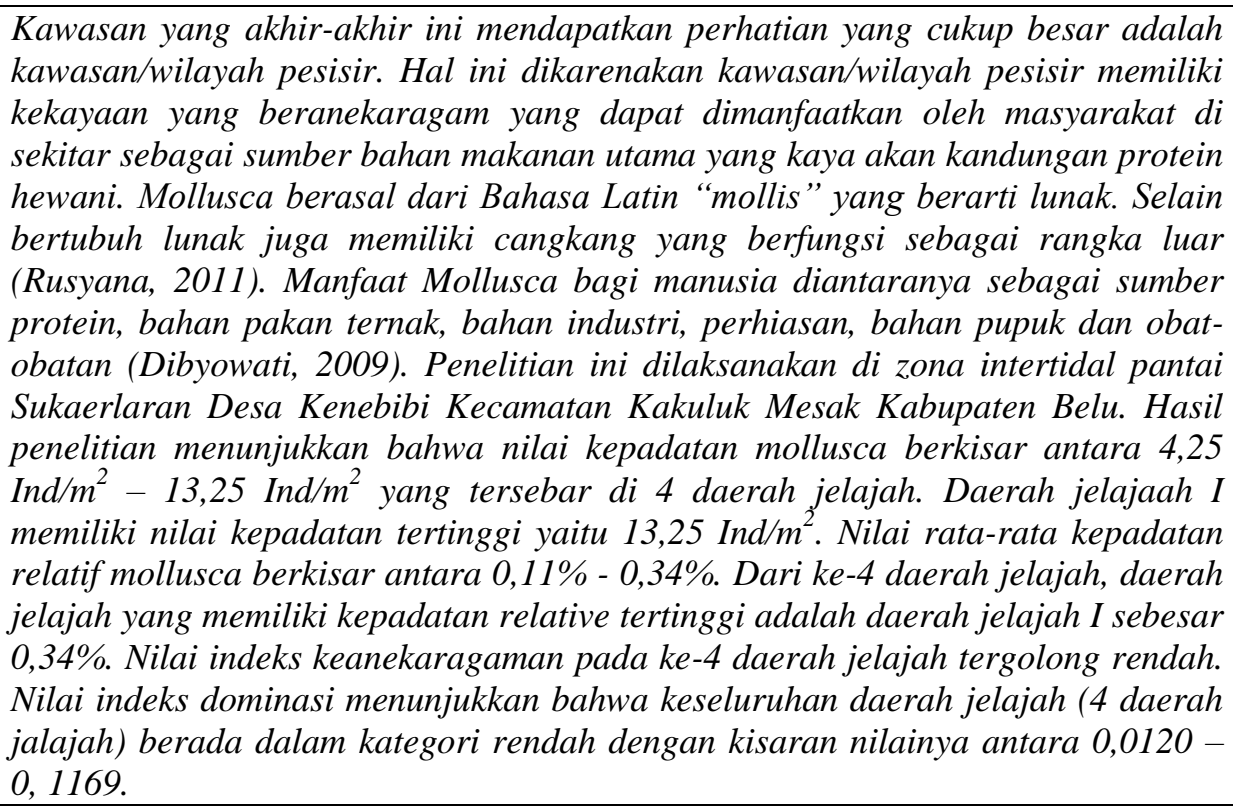 \\
\hline
\end{tabular}




\section{PENDAHULUAN}

Kawasan yang akhir-akhir ini mendapatkan perhatian yang cukup besar dalam berbagai kebijakan dan perencanaan pembangunan di Indonesia adalah kawasan/wilayah pesisir. Hal ini dikarenakan kawasan/wilayah pesisir memiliki kekayaan yang beranekaragam yang dapat dimanfaatkan oleh masyarakat di sekitar sebagai sumber bahan makanan utama yang kaya akan kandungan protein hewani.

Asupan protein hewani yang diperoleh dari daerah pesisir (zona intertidal) akan semakin berkurang apabila substrat dari organisme-organisme yang mendiaminya mengalami kerusakan. Hal ini diperkuat oleh Odum (1994) bahwa lingkungan fisik, kimia, dan biologi suatu ekosistem akan mempengaruhi biota atau organisme yang terdapat di dalamnya. Selain itu, segala bentuk aktivitas manusia di daerah pesisir (zona intertidal) juga merupakan salah satu faktor yang mempengaruhi kehidupan organisme-organisme di daerah tersebut.

Mollusca berasal dari Bahasa Latin "mollis" yang berarti lunak. Selain bertubuh lunak Mollusca juga memiliki cangkang yang berfungsi sebagai rangka luar (Rusyana, 2011). Mollusca mempunyai dua kelas terbesar yaitu Bivalvia dan Gastropoda. Ukuran tubuh dan cangkang pada Mollusca sangat beraneka ragam (Septiani, 2017). Modifikasi cangkang pada Mollusca inilah yang digunakan untuk membedakan antara anggota kelas Bivalvia dan anggota kelas Gastropoda. Pada Bivalvia terdapat dua cangkang yang melekat pada dorsal, sedangkan Gastropoda memiliki karakteristik cangkang tunggal bergulir. Mollusca mempunyai beberapa manfaat bagi manusia diantaranya sebagai sumber protein, bahan pakan ternak, bahan industri, perhiasan, bahan pupuk dan obat-obatan (Dibyowati, 2009).

Adanya tumbuhan mangrove, lamun, dan terumbu karang pada beberapa lokasi di zona intertidal Pantai Sukaerlaran dapat menunjukkan keberagaman biota yang berasosiasi di dalamnya, salah satunya adalah Mollusca (Islami, 2013). Menurut Hendrick (2007), mollusca memiliki sifat infauna atau semi-infauna yang mendiami habitat berpasir dan berlumpur di kawasan intertidal sebagai penyusun komunitas macrozoobentos yang dapat digunakan sebagai bioindikator pada ekosistem perairan.

Meskipun demikian catatan penelitian tentang Mollusca di pantai Sukaerlaran masih sangat terbatas bahkan belum ada penelitian tentang Mollusca di pantai ini. Beberapa penelitian pernah dilakukan di pantai Atapupu khususnya di Pantai Raikatar yang merupakan pantai yang berbatasan dengan pantai Sukaerlaran, namun fokus penelitiannya pada Echinoidea dan Holothuroidea.

Berdasarkan kondisi di atas, maka keberadaan Mollusca di Pantai Sukaerlaran menjadi penting untuk dikaji guna mengetahu kelimpahan dan komposisi jenis Mollusca yang ada. Kajian ini difokuskan pada pengamatan komunitas Mollusca. Hasil studi ini diharapkan dapat memberikan tambahan informasi mengenai kondisi fauna Mollusca yang ada di zona intertidal Pantai Sukaerlaran terutama Bivalvia dan Gastropoda.

\section{METODE PENELITIAN}

Pengambilan sampel Mollusca (Bivalvia dan Gastropoda) dilakukan pada bulan Desember 2018 menggunakan metode cruising/jelajah, teknik pencuplikan yang digunakan adalah pencuplikan hand sorting/koleksi langsung. Waktu pengambilan sampel dilakukan saat pasang surut terendah yaitu pada pukul 08.00-11.00 WITA. Daerah keseluruhan jelajah adalah $2 \mathrm{~km}$, dibagi dalam 4 daerah jelajah yaitu daerah jelajah I (500 m), daerah jelajah II (1000 m), daerah jelajah III (1500 m) dan daerah jelajah IV (2000 m).

Mollusca (Bivalvia dan Gastropoda) yang diperoleh pada saat cruising dikumpulkan dalam wadah (toples) yang telah disediakan kemudian dicuci dan selanjutnya diawetkan menggunakan alcohol $70 \%$ lalu diberi label. Semua Bivalvia dan Gastropoda hidup yang ditemukan pada masingmasing daerah jelajah dihitung jumlahnya dan diidentifikasi menurut Abbot \& Dance, 1990.

Analisis data yang digunakan untuk mengetahui komunitas Mollusca (Bivalvia dan Gastropoda) di zona intertidal Pantai Sukaerlaran yaitu: 


\subsection{Kepadatan}

2.1.1. Kepadatan Spesies (Cox, 1967. dimodifikasi)

$\mathbf{D}=\frac{\mathbf{N i}}{\mathbf{A}}$

Keterangan:

$\mathrm{D}=$ Kepadatan moluska $\left(\mathrm{Ind} / \mathrm{m}^{2}\right)$

$\mathrm{Ni}=\mathrm{Jml}$ individu spesies moluska

A $=$ Luas total area pengambilan sampel $\left(\mathrm{m}^{2}\right)$

\subsubsection{Kepadatan Relatif (\%)}

$\mathbf{R D}=\frac{\mathbf{N i}}{\Sigma \mathbf{A}}$

Keterangan:

$\mathrm{RD}=$ Kepadatan Relatif moluska (\%)

$\mathrm{Ni}=\mathrm{Jml}$ individu spesies moluska

$\Sigma \mathrm{A}=$ Total individu

2.2. Indeks Keanekaragam Spesies

$\mathbf{H}^{\prime}=-\sum_{\mathbf{i}=\mathbf{1}}^{\mathbf{s}} \mathbf{P i} \ln \mathbf{P i}$,dimana $\mathrm{Pi}=\frac{\text { ni }}{\mathrm{N}}$

Keterangan:

$\mathrm{H}^{\prime}=$ Indeks diversitas Shannon-Wiener

$\mathrm{Pi}=\mathrm{ni} / \mathrm{N}$ (proporsi jenis ke-i)

$\mathrm{N}=\mathrm{Jml}$ total individu

$\mathrm{S}=\mathrm{Jml}$ spesies

Kriteria indeks keanekaragaman menurut Shannon-Wiener ( $\left.\mathrm{H}^{\prime}\right)$ adalah sebagai berikut : Tabel 2.1. Kriteria indeks keanekaragaman Shannon-Wiener ( $\left.\mathrm{H}^{\prime}\right)$

\begin{tabular}{ll}
\hline & \multicolumn{1}{c}{ H' $^{\prime}$ Kriteria } \\
\hline $\mathrm{H}^{\prime}<1$ & Keanekaragaman rendah \\
$1<\mathrm{H}^{\prime}<3$ & Keanekaragaman sedang \\
$\mathrm{H}^{\prime}<3$ & Keanekaragaman tinggi \\
\hline
\end{tabular}

2.3. Indeks Dominasi

$\mathbf{C}=\sum\left(\frac{\mathrm{ni}}{\mathrm{N}}\right)^{2}$

Keterangan:

$\mathrm{ni}=\mathrm{Jml}$ individu tiap spesies

$\mathrm{N}=\mathrm{Jml}$ individu seluruh spesies

Tabel 2.2. Kriteria indeks dominasi (C)

\begin{tabular}{ll}
\hline & \multicolumn{1}{c}{ Kriteria } \\
\hline $00,0<\mathrm{C} \leq 0,30$ & Dominasi rendah \\
$0,30<\mathrm{C} \leq 0,60$ & Dominasi sedang \\
$0,60<\mathrm{C} \leq 1,00$ & Dominasi tinggi \\
\hline
\end{tabular}

Septiani, 2017 


\section{HASIL DAN ANALISA}

\subsection{Kepadatan}

\subsubsection{Kepadatan Mollusca}

Nilai kepadatan mollusca di zona intertidal Pantai Sukaerlaran berkisar antara 4,25 $\mathrm{Ind} / \mathrm{m}^{2}-13,25 \mathrm{Ind} / \mathrm{m}^{2}$ yang tersebar di 4 daerah jelajah. Daerah jelajaah I memiliki nilai kepadatan tertinggi yaitu $13,25 \mathrm{Ind} / \mathrm{m}^{2}$. Hal ini karena daerah jelajah I memiliki kondisi lingkungan yang didominasi pasir berbatu, bongkahan karang, dan terdapat tumbuhan laut, misalnya lamun. Lingkungan seperti ini cukup mendukung dan produktif untuk pertumbuhan Mollusca terutama Gastropoda.

Sementara nilai kepadatan terendah terdapat di daerah jelajah III yaitu $4,25 \mathrm{Ind} / \mathrm{m}^{2}$. Daerah jelajah III merupakan tipe substrat yang berpasir halus. Tipe substrat seperti ini kurang menunjang kehidupan mollusca. Substrat seperti ini tidak menyediakan tempat yang tetap untuk melekatkan tubuh sehingga lokasi ini tidak banyak ditemukan Gastropoda. Bivalvia ditemukan di daerah ini karena Bivalvia dapat bertahan dan hidup di substrat berpasir. Tipe substart berpasir juga memudahkan Bivalvia dalam memperoleh makanan dan air unntuk mempertahankan kelangsungan hidupnya (Dibyowati, 2009). Jenis Gastropoda yang ditemukan pada daerah jelajah III adalah jenis Nassaridae, karena jenis ini mampu bertahan hidup karena didukung oleh morfologi cangkangnya, yaitu memiliki aperture yang rata dan halus. Aperture ini berfungsi untuk meluncur dengan sangat cepat pada substrat berpasir.

Perbedaan nilai kepadatan pada masing-masing daerah jelajah disebabkan oleh perbedaan karakteristik fisik dan variasi substrat. Variasi substrat memberikan pengaruh yang besar terhadap kehadiran organisme, yaitu semakin beragamnya substrat penyusunnya maka semakin banyak pula komposisi jenis komunitas yang ditemukan (Fajri, 2013).

Grafik nilai kepadatan mollusca pada masing-masing daerah jelajah tersaji dalam Gambar 4.1.

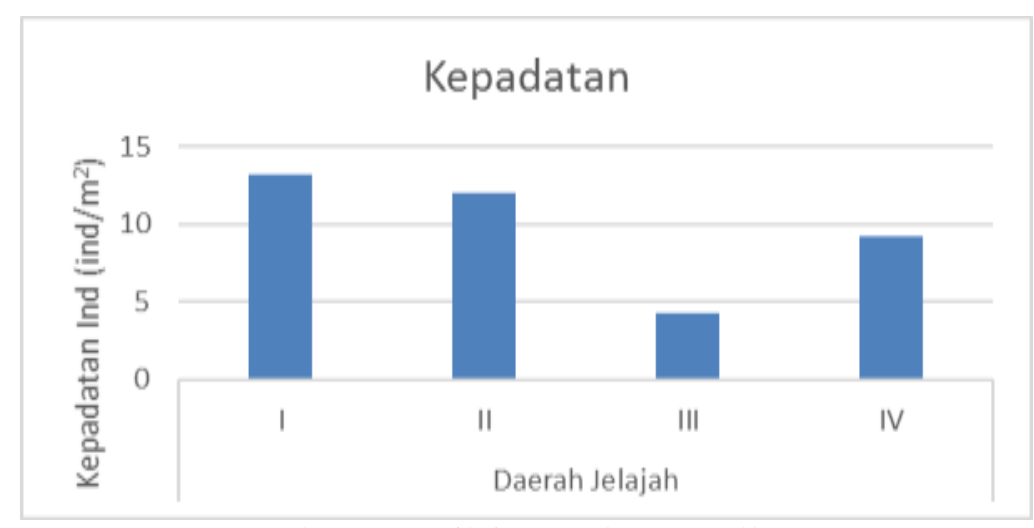

Gambar 4.1. Nilai Kepadatan Mollusca

Kepadatan suatu individu atau spesies bertujuan untuk mengetahui individu atau spesies yang hidup pada habitat dan dalam waktu tertentu (Dibyowati, 2009). Nilai kepadatan tertinggi suatu individu menunjukkan bahwa terdapat jumlah suatu organisme yang melimpah daerah tersebut. Selain itu kepadatan tertinggi juga berhubungan dengan cara hidup dan daya toleransi yang baik terhadap lingkungan.

\subsubsection{Kepadatan Relatif}

Hasil penelitian menunjukkan bahwa nilai rata-rata kepadatan relatif mollusca di zona intertidal Pantai Sukaerlaran berkisar antara 0,11\% - 0,34\%. Dari ke-4 daerah jelajah, daerah jelajah yang memiliki kepadatan relatif tertinggi adalah daerah jelajah I sebesar 0,34\%, 
sedangkan daerah jelajah yang memiliki kepadatan relatif terendah adalah daerah jelajah III sebesar $0,11 \%$.

Menurut Hawari (2014), kepadatan mollusca (Bivalvia) umumnya dijumpai pada daerah penelitian yang memiliki tipe substrat lumpur atau lumpur berpasir. Sementara Gastropoda menurut Gosling (2003), merupakan makrozoobentos yang dapat hidup di berbagai tipe substrat pasir, batu, lumpur. Tanjung (1995) menyatakan bahwa Gastropoda mempunyai kemampuan adaptasi yang lebih tinggi disbanding dengan hewan benthos lainnya, karena didukung oleh struktur tubuh yang bercangkang yang dapat memperkecil pengaruh hempasan ombak dan sifatnya yang menempel dan dapat menggali lubang pada substrat tempat hidupnya. Hal ini diperkuat lagi oleh pernyataan Fajri \& Reni (2013), bahwa kepadatan relatif Mollusca (Gastropoda) relatif tinggi pada pantai berbatu karena disebabkan oleh daya tahan tubuh dan adaptasi cangkang yang keras sehingga memungkinkan hewan jenis ini mampu bertahan hidup dibandingkan jenis hewan yang lainnya.

Grafik nilai kepadatan relatif mollusca pada masing-masing daerah jelajah disajikan pada gambar 4.2.

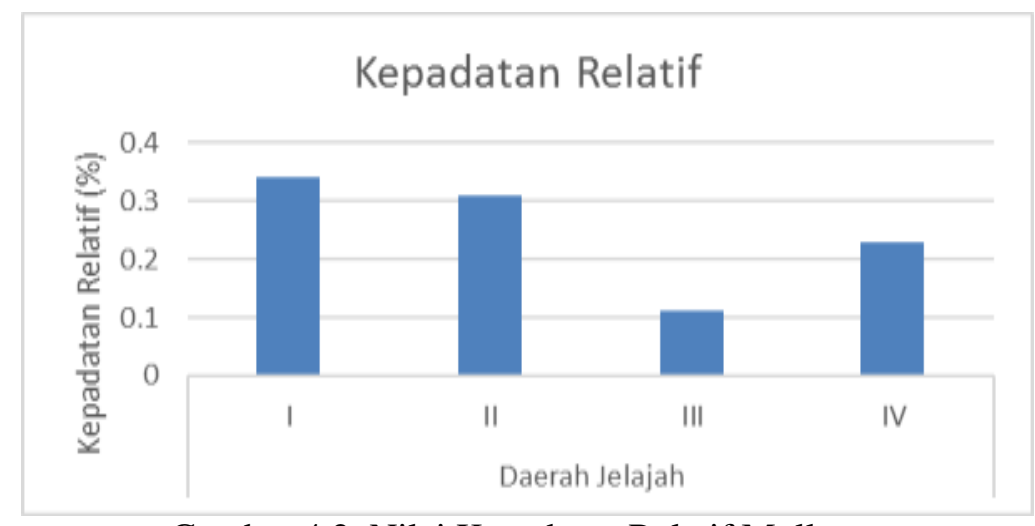

Gambar 4.2. Nilai Kepadatan Relatif Mollusca

\subsection{Indeks Keanekaragaman}

Berdasarkan hasil penelitian yang dilakukan di Pantai Sukaerlaran Desa Kenebibi Kecamatan Kakuluk Mesak Kabupaten Belu, diperoleh indeks keanekaragaman Mollusca pada 4 daerah jelajah disajikan pada Tabel 4.1.

Tabel 4.1. Indeks Keanekaragaman (H') Molluska

\begin{tabular}{lcccc}
\hline & \multicolumn{4}{c}{ Daerah Jelajah } \\
\cline { 2 - 5 } & I & II & III & IV \\
\hline H$^{\prime}$ & $-0,3669$ & $-0,3630$ & $-0,2424$ & $-0,3419$ \\
\hline Kriteri & Keanekaragaman & Keanekaragama & Keanekaragama & Keanekaragama \\
a & Rendah & n Rendah & n Rendah & n Rendah \\
\hline
\end{tabular}

Berdasarkan hasil perhitungan indeks keanekaragaman Mollusca di Pantai Sukaerlaran pada Tabel 4.1 menunjukkan bahwa nilai indeks keanekaragaman pada ke-4 daerah jelajah tergolong rendah. Indeks kenanekaragaman di Pantai Sukaerlaran dikatakan rendah karena dipengaruhi oleh faktor fisika-kimia perairan tersebut seperti suhu, $\mathrm{pH}$, kecerahan, TSS, dan DO. Menurut Irma (2004), tidak meratanya jumlah individu untuk setiap spesies berhubungan dengan pola adaptasi masing-masing spesies, seperti tersedianya berbagai tipe substrat, makanan, dan kondisi lingkungan. Selain itu arus gelombang juga sangat berpengaruh terhadap keanekaragaman Mollusca, daerah dengan aliran gelombang yang kuat memiliki keanekaragaman rendah dibandingkan dengan yang berarus lemah (Ira et al, 2015). Aktivitas masyarakat juga dapat mempengaruhi kelangsungan hidup Mollusca seperti menginjak-injak substrat serta pengambilan jenis Mollusca jenis kerang-kerangan untuk dikoleksi secara pribadi. 


\subsection{Indeks Dominasi}

Nilai indeks dominasi bertujuan untuk mengetahui jumlah individu tiap jenis. Hasil analisis indeks dominasi menunjukkan bahwa keseluruhan daerah jelajah (4 daerah jalajah) berada dalam kategori rendah dengan kisaran nilainya antara $0,0120-0,1169$. Nilai indeks dominasi pada ke-4 daerah jelajah disajikan pada Tabel 4.2.

Tabel 4.2. Indeks Dominasi (C) Molluska

\begin{tabular}{lcccc}
\hline & \multicolumn{4}{c}{ Daerah Jelajah } \\
\cline { 2 - 5 } & I & II & III & IV \\
\hline C & 0,1169 & 0,0959 & 0,0120 & 0,0569 \\
\hline Kriteri & Dominasi Rendah & Dominasi & Dominasi & Dominasi \\
a & & Rendah & Rendah & Rendah \\
\hline
\end{tabular}

Hasil analisis pada Tabel 4.2 menunjukkan bahwa tidak ada individu yang dominan di daerah penelitian artinya bahwa belum terjadi persaingan yang berarti terhadap ruang, makanan, atau tempat hidup bagi organisme Mollusca tersebut. Hal ini diperkuat oleh pernyataan Syamsurial (2011) yang menyatakan bahwa nilai indeks dominasi yang tinggi menyatakan konsentrasi dominan yang tinggi (adanya individu yang dominan), sebaliknya jika indeks dominasi rendah menyatakan konsentrasi dominan yang rendah (tidak ada yang dominan).

\section{KESIMPULAN}

Berdasarkan hasil penelitian ini dapat disimpulkan bahwa perbedaan karakteristik fisik dan variasi substrat akan memberikan pengaruh pada organisme yang ada di dalamnya. Hal inilah yang mempengaruhi kepadatan spesies, keanekaragaman spesies dan dominasi spesies pada suatu habitat. Namun kemampuan beradaptasi dari suatu spesies juga sangat berpengaruh terhadap keberadaan suatu organisme.

Saran dan rekomendasi yang dapat diberikan penulis bagi pembaca maupun peneliti Mollusca lainnya, untuk melakukan penelitian lanjutan berkaitan dengan pengukuran lingkungan fisika-kimia di Pantai Sukaerlaran, kandungan logam di Pantai Sukaerlaran, dan pengaruh aktifitas masyarakat terhadap perubahan yang dapat ditimbulkan pada sumberdaya perairan di Pantai Sukaerlaran.

\section{ACKNOWLEDGEMENTS}

Terima kasih kepada pihak pemerintah khususnya Kepala Desa Kenebibi Kecamatan Kakuluk Mesak Kabupaten Belu yang telah bersedia memberikan tempat penginapan serta memberikan izin kepada peneliti untuk melakukan penelitian di Pantai Sukaerlaran. 


\section{DAFTAR PUSTAKA}

Dibyowati, L. 2009. Keanekaragaman Mollusca (Bivalvia dan Gastropoda) di Sepanjang Pantai Carita, Padeglang Banten. Skripsi. Bogor: Institut Pertanian Bogor

Fajri, N. 2013. Struktur Komunitas Makrozoobentos di Perairan Pantai Kuwang Wae Kabupaten Lombok Timur. Jurnal Educatio: 8 (2), 89

Fajri, N. E and R. Agustina. 2013. Penuntun Praktikum Ekologi Perairan. Laboratorium Ekologi dan Manajemen Lingkungan Perairan Jurusan Manajemen Sumberdaya Perairan Fakultas Perikanan dan Ilmu Kelautan Universitas Riau. Pekanbaru

Gosling, E. 2003. Bivalva Mollusc Biology Ecology and Culture. Fishing Newa Books, Blackwell Publishing. Great Britain. $445 \mathrm{p}$

Hawari, A. 2014. Hubungan Antara Bahan Organik Sedimen dengan Kepadatan Makrozoobenthos di Perairan Pantai Pandan Provinsi Sumatera Utara. Skripsi Fakultas Perikanan dan Ilmu Kelautan Universitas Riau Lombok Timur. Jurnal Education: 8 (2), 89

Ira et al. 2015. Keanekaragaman dan Kepadatan Gastropoda di Perairan Desa Morindino Kecamatan Kambowa Kabupaten Buton Utara. Jurnal Ilmu Perikanan dan Sumberdaya Perikanan. Hal. 269

Odum, E. P. 1994. Dasar-Dasar Ekologi. Edisi Ketiga. Yogyakarta: Gadjah Mada University Press

Rusyana, A. 2011. Zoologi Invertebrata (Teori dan Praktik). Bandung: Alfabet

Septiani, N. I. 2017. Keanekaragaman Moluska (Bivalvia dan Gastropoda) di Pantai Pasir Putih Kabupaten Lampung Selatan. Skripsi Fakultas Tarbiyah dan Keguruan Universitas Islam Negeri Raden Intan Lampung: hal.48

Syamsurial. 2011. Studi Beberapa Indeks Komunitas Makrozoobentos di Hutan Mangrove Kelurahan Coppo Kabupaten Baru. Skripsi Program Studi Perikanan Fakultas Ilmu Kelautan dan Perikanan Universitas Hasanudin. Makasar

Tanjung, A. 1995. Distribusi Makrozoobenthos di Zona Intertidal Selat Morong Kabupaten Bengkalis Riau. Pusat Penelitian Universitas Riau. Pekanbaru 